https://oi.org/10.19195/0080-3626.65.5

\author{
AUŠRA NAVICKIENĖ \\ ORCID: 0000-0002-6040-9882 \\ Vilniaus Universitetas
}

\title{
PROFESSIONAL PUBLISHING AND LITHUANIAN BOOKS IN THE FIRST TWO-THIRDS OF THE 19TH CENTURY IN LITHUANIA: THE CASE OF THE ZAWADZKI FIRM
}

The article deals with Józef Zawadzki's private company, the most important and most successful book publishing, production, and distribution firm of $19^{\text {th }}$ century Lithuania. The author discusses one segment of its activity: Lithuanian book publishing and distribution during the first sixty years of its existence, starting from its establishment in 1805 until the imposition of the press ban in 1864 . The main sources of research are the data of the Lithuanian retrospective bibliography (the volumes of Lithuanian National Retrospective Bibliography, series A), archival material on the Zawadzki enterprise, the published and unpublished correspondence of those involved in Lithuanian book publishing and commerce, and de visu examination of Lithuanian books.

KEY WORDS: Józef Zawadzki, Adam Zawadzki, nineteenth century publishing in Lithuania, Lithuanian books, Varniai book shop

Book researchers call the $19^{\text {th }}$ century the age of the European national book (Migon, 2009, p. 187). The increase in quantity and quality of books published in national languages was a distinct feature of the period. In Lithuania, the $19^{\text {th }}$ century began after the third partition of the Polish-Lithuanian Commonwealth in 1795 and lasted until the abolition of the press ban in 1904. It coincided with the loss of the state and the first century of the Russian occupation. The start of the prohibition on the use of Latin characters in the Lithuanian press in 1864 can be considered a dividing line that separates the period into two parts, characterized by fundamentally different circumstances for book publishing businesses. During the first two-thirds of the $19^{\text {th }}$ century, Lithuanian books ${ }^{1}$ were published

1 The term "Lithuanian book" encompasses all printed works in the Lithuanian language, whose main purpose was to meet needs of the population of the territory. The following character- 
in Lithuania, ${ }^{2}$ or the Lithuanian ethnic territory annexed by Russia Empire, and Lithuania Minor, ${ }^{3}$ a territory inhabited by so-called Prussian Lithuanians (or lietuvininkai) on the left bank of the river Nemunas (a part of Prussia and, after 1871, a part of the German Empire). Due to the various political, legal, religious and intellectual influences, the main forces of Lithuanian book authors and publishers began to gather in Lithuania, where 588 Lithuanian books were published during that period (Navickiene, 2010, p. 38). For the first time since the beginning of printing of Lithuanian books, Lithuania caught up with and overtook Lithuania Minor, which had previously taken first place in publishing Lithuanian books.

In the $19^{\text {th }}$ century, the prevalent publications in Lithuania were those not in the Lithuanian language. Based on the reports of Vilnius censorship institutions ${ }^{4}$ (which contain information about permissions to publish books issued by the Vilnius Censorship Committee and may be considered as reflecting the language structure of the publishing output of the country), it may be stated that in the fourth and fifth decades of the $19^{\text {th }}$ century, the printed matter published in Lithuania consisted of 51\% publications in Polish, 27\% in Hebrew, 9\% in Russian, and $13 \%$ in other languages, the latter presumably containing about $5 \%$ publications in Lithuanian. ${ }^{5}$ From the beginning of the century, writing and publishing of books in Lithuanian language became a method of expression for participants in the National Revival and a means of combating for the preservation of nationality. However, publishing volume began to grow significantly in the $1830 \mathrm{~s}$, when professional publishers (private printers and book traders) found commercial interest in and began making a significant contribution to the publishing of Lithu-

istics are recognized as distinguishing for a Lithuanian book of a certain region: a book's address, place of preparation and publication, content, author, and alphabet. Based on these characteristics, the Lithuanian book of Lithuania Minor is distinguished from that of Lithuania. In the period under study, these two types of Lithuanian books existed as two independent, almost unrelated book worlds, which were separated by state borders, influenced by various cultures, languages and religious traditions, and met the respective needs of Lithuanians and Prussian Lithuanians.

${ }^{2}$ Lithuania is a term used to define the Lithuanian ethnic territory stretching northwards and eastwards from the border between Prussian territory and the Grand Duchy of Lithuania, ruled by Grand Duchy of Lithuania and later, from 1795/1815 to 1915, by the Russian Empire, since 1918 the Independent Republic of Lithuania, since 1940 annexed by the USSR, and, finally, from 1990 roughly coinciding with the territory of the re-established Independent Republic of Lithuania.

${ }^{3}$ Lithuania Minor is a term used to define the territory on the left bank on the river Nemunas, which was annexed by Teutonic orders in the $13^{\text {th }}$ century, later belonged to Prussia and after 1871 was part of the German Empire. The term appeared for the first time between 1517 and 1526 . Beginning in the sixteenth century, it became a Lithuanian province, as opposed to Lithuania. Today a small portion of Lithuania Minor is within borders of modern Lithuania, while most of the territory is part of Kaliningrad Oblast in Russia.

${ }^{4}$ Perepiska..., 1844.

5 Since Lithuanian books are not specified in the above-mentioned document, their publishing volume has been calculated based on the data from the Lithuanian National Retrospective Bibliography, Series A. 
anian books. This new group of publishers appeared in Lithuania in the beginning of the $19^{\text {th }}$ century and replaced the old Catholic Church printing houses, which had dominated in the publishing of Lithuanian book in earlier centuries. Private printers and book traders were oriented by commercial incentives towards mass production and popular books for religious practice and primary education. Lithuanian books became an object of commerce in part due to the fact that already in the early $19^{\text {th }}$ century, Lithuania was one of the most literate regions of the Russian Empire, and the formation of a more economically-capable class of peasants, which was driven to education by changes in the economic and social life, led to the increase of readers and buyers of Lithuanian books.

The article will deal with Lithuanian book publishing by Józef Zawadzki's private company, one of the first in a new category of professional publisher, the most important and most successful book publishing, production, and distribution firm of the $19^{\text {th }}$ century. The activities of this company, which had been in operation for one hundred and thirty-four years, attracted attention of Polish and Lithuanian researchers. Scholars from both interwar Vilnius (Abramowicz, 1925; Turkowski, 1935-1937) and Soviet-era Poland (Cybulski, 1960; 1963; 1972; 1976; Poklewska, 1972) and Lithuania (Abramavičius, 1940; 1955; Merkys, 1972; Petkevičiūtè, 1984; Rozet, 1960; Shul'kina, 1962; Tyla, 1968), published archival documents and wrote about the Zawadzki firm. Research into this subject has also been ongoing in recent decades (Navickienè, 1996; 2005; 2007; 2016). Summarizing the state of the historiography, we can say that the first three decades of the firm's activity have received the most research attention so far, and the research on this period culminates in R. Cybulskis's monograph. The firm's publishing of Lithuanian books has not been systematically analyzed, so the aim of this article is to continue the research on Zawadzki's publishing of Lithuanian books by systematizing the results of previous research and new data from various bibliographical and archival sources. The article will attempt to find answers to the following issues, which are still relevant: What was the scope of firm's published Lithuanian books in the period from 1795 to 1864 ? What were the most important publications? What circumstances aroused the Zawadzki family's interest in publishing Lithuanian books? How did Zawadzki's publications contribute to the renewal, democratization and secularization of Lithuanian books publishing repertoire? How did they reach Lithuanian readers?

Different bibliographical sources were referred to and surviving copies of publications were analysed de visu in order to reconstruct the publishing output of the Zawadzki firm, but the volumes of the Lithuanian National Retrospective Bibliography, Series A, were the most important. ${ }^{6}$ Using various criteria, books

${ }^{6}$ Lietuvos TSR bibliografija, 1969, p. 728; 1985, p. 957; 1988, p. 854; Lietuvos bibliografija, 1990, p. 152. 
published by the Zawadzki firm were identified and an original bibliographical register was compiled. It allowed the researchers to clarify the scope of the firm's Lithuanian production and to identify the most important publications. The Zawadzkiai, as modern entrepreneurs and professional publishers combining the activities of book publishing, production and distribution, were used to marking "publisher" on the title page of their publications, especially after 1830, when copyright law was adopted in Russia and the legal foundations were laid not only for the protection of authors, but also for the protection of publishers' property. However, in cases where it was necessary to rely solely on the data recorded in bibliographies for information on the publisher, and where it was not possible to examine the editions in their entirety (not all copies of the editions have survived to the present day), additional information on the publisher was provided by the archival sources - the correspondence of Lithuanian book authors with Adam Zawadzki. ${ }^{7}$ The correspondence was also important for clarifying the circumstances of the publication of Lithuanian books. The channels of publications' distribution were analyzed, using documents from the Zawadzki enterprise archive. ${ }^{8}$

Summarizing materials drawn from various sources, it may be stated that in 1805-1864, 172 Lithuanian books were printed at the firm's printing house: 122 of them at the firm's expense and about 50 Lithuanian publications at that of the authors. The Zawadzki firm stood apart from other publishers of those times by volume of publications and may be defined as the most important publisher and printer of Lithuanian books. In comparison, it may be mentioned data on all the publishers of Lithuanian books in 1795-1864: all institutional and private printing house published/financed 337 Lithuanian books; bookstores, 34 Lithuanian books; numerous private individuals, 119 books; and various non-commercial institutions and organizations, 98 Lithuanian books (Navickienè, 2010, p. 45).

Commercially-motivated members of Zawadzki family selected manuscripts, signed contracts with authors and translators of manuscripts, used their own finances or pooled funding for publishing, printed them at their printing house and distributed published matter themselves, using various methods of advertising.

${ }^{7}$ For published sources see: Daukantas, 1976; Griškaite, Šenavičienè, 1996; Navickienė, 2007; Turkowski, 1935-1937; Ivinskio..., 1995, pp. 403-491. For archival sources see: [Akelaičio...], 1856; [Budriko...], 1856; [Gomaliausko...], 1851; [Ivinskio Lauryno...], 1850-1861; [Juzumų...], 18541856; [Kun. Ulinskio...], 1858; [Praniausko...], 1854-1861; [Prialgauskio...], 1859; [Račkauskio Jeronimo laiškai Adomui Zavadzkiui], 1853-1861; [Račkauskio Jeronimo laiškas Juozapo Zavadzkio knygynui], 1856; [Skrodzkio...], 1856; [Valančiaus...], 1851; [Želvavičiaus...], 1850-1860.

${ }^{8}$ Zhurnal..., 1853-1865; Kniga registratsii otpravlennykh zakazov knig, 1853-1865; Kniga registratsii prodazhi knig, 1861-1862; 1864-1866; Kniga registratsii prodazhi knig, khudozhestvennoy literatury, uchebnikov, slovarey, 1853-1856; Kniga registratsii prodazhi not, knig i periodicheskikh izdaniy, 1861-1863. 
It is possible to distinguish two periods of the firm's activity, when both the approach to Lithuanian book publishing and its volumes differed. The first period is related to the activities of the firm's founder, Józef Zawadzki (1781-1838), and the second to the activities of the company's heir, Adam Zawadzki (1814-1875).

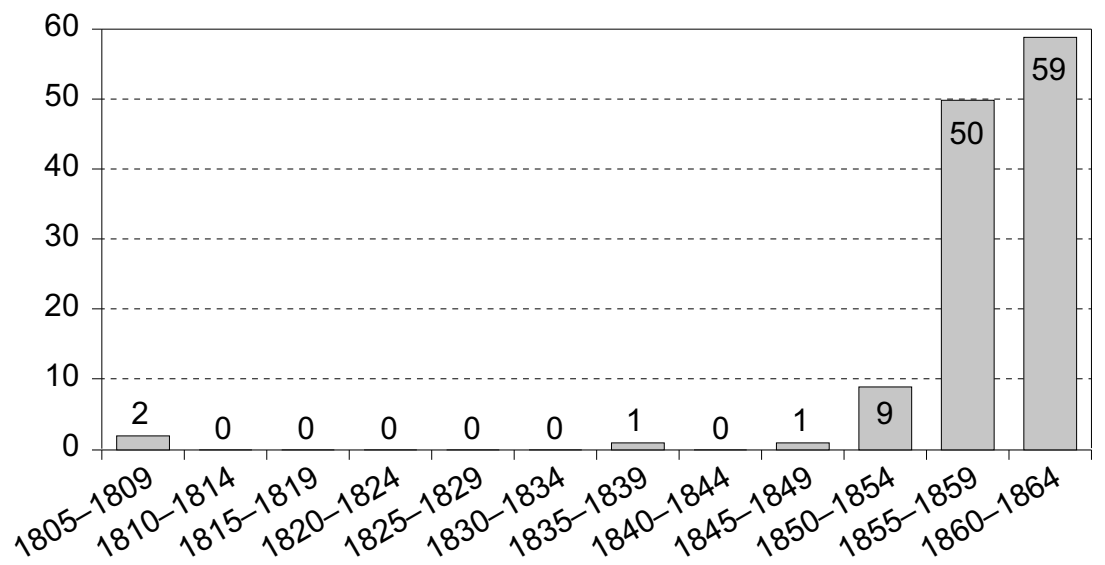

Fig. 1. Publishing of Lithuanian books by the Zawadzki firm in 1805-1864. Source: own study

Józef Zawadzki studied the book business in Wrocław, Poznań and Leipzig, and moved to Vilnius in 1803. In Vilnius, he created the most innovative printing house and bookstore and began implementing the modern book publishing business model. In 1805-1828, when the firm operated as the printing house of the Imperial Vilnius University and its publishing activities were oriented towards textbooks and other publications needed by the university, the founder invested in the publishing of Polish books and published only two Lithuanian ones.

There is no doubt as to the attribution to this firm of Lietuwiszkas ewangelias niedielos dienomis yn ant garbingiesniu szwęciu [... $]^{9}$ (Lithuanian Gospels for weekdays and more important holidays [...], 1806), a publication distinguished by its content following the standardization of the Lithuanian language (the texts of Gospels were prepared by Bonaventūra Gailevičius and a group of priests from Samogitia). Perhaps the publication was expected to be as popular as the Gospels prepared by Jonas Jaknavičius (1589-1668), a book which was reprinted every 4-5 years over a period of two hundred years. But the project was unsuccessful. Because the Gospels were read in churches in both languages (Polish and Lithuanian), the new publication only in the Lithuanian language was apparently inconvenient for priests, and copies of this publication could be found in Zawadzki's Vilnius bookstore even 50 years after its publication.

${ }^{9}$ Lithuanian titles are given in original orthography as they were published at the time. 


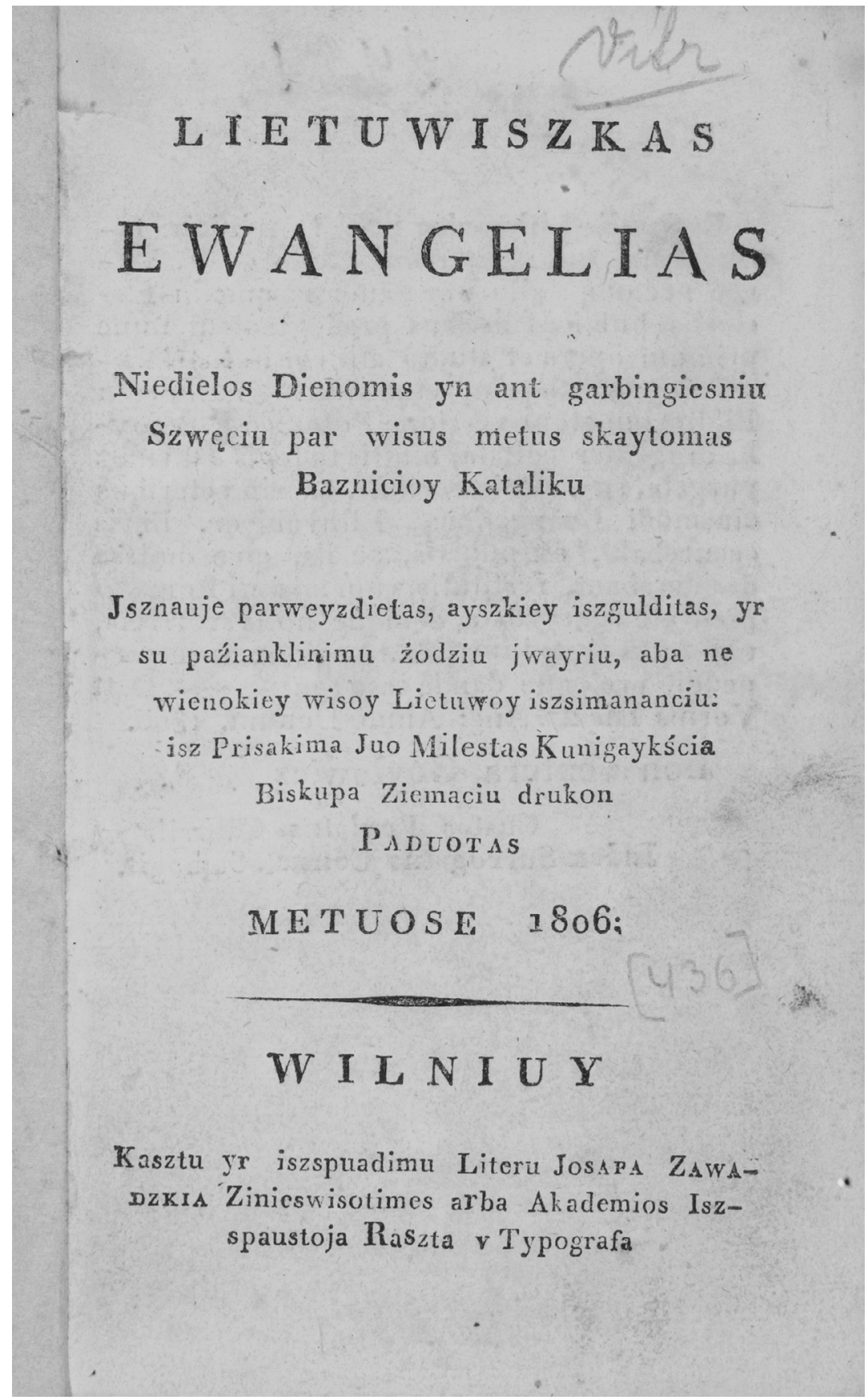

Fig. 2. The first Lithuanian publication of the Zawadzki firm - Lietuwiszkas ewangelias niedielos dienomis yn ant garbingiesniu szwęciu [...] (1806) 
Researchers' opinions differ regarding another publication, an $\mathrm{ABC}$ book Mokstas skaytima raszta lietuviszka [...] (The science of reading Lithuanian script for small children [...], 1809), the most popular primer of the $19^{\text {th }}$ century. Based on Zawadzki's book catalogue, ${ }^{10}$ the bibliographers Karol Estreicher, Silvestras Baltramaitis and Vaclovas Biržiška attributed the book to Józef Zawadzki (Estreicher, 1870, p. 3; Baltramaytis, 1904; Biržiška, 1926). More than half a century later, the compilers of a Lithuanian retrospective bibliography offered a different opinion on this publication (Lietuvos TSR bibliografija, 1969, p. 269). Their doubts were aroused by the fact that the aforementioned catalogue by J. Zawadzki lists not only books issued by his printing house, but also other books sold in his bookstore. So far, no new evidence has been found to confirm or disprove the existence of such a publication. In any case, in the period of 1805-1838, Lithuanian-language publications accounted for less than one percent of all the firm's publications. ${ }^{11}$

J. Zawadzki had three sons: Józef, Adam, and Felix. Józef settled down in Kiev, where he rented the printing house of a local university. At first, all three brothers were owners of the Vilnius printing house. Their father's name remained part of the company's name. The legal owners swiftly changed: Adam handled publishing affairs and the printing house, and his wife, Wincenta Zawadzka, managed the bookstore. The company was headed (at first, behind the scenes, and later, officially) by the Vilnius university-educated Adam, and his brother Felix contributed to the book trade's organization (Merkys, 1972, p. 233).

Adam had to struggle with the company's economic decline, caused by the constant competition with Teofil Glücksberg, a new privileged Vilnius University typographer, who in 1827 won the position of Vilnius University's book printer and book distributor, and with the local Jews, a group increasingly dominant in the local book business. Starting from the fifth decade, he began to print books by Lithuanian authors. When, in the early sixth decade, the influential Bishop of Samogitia, Motiejus Valančius, ${ }^{12}$ distinguished him from other printers and book distributors, Adam Zawadzki embarked on publishing Lithuanian books. Adjusting to the new realities, in 1853, Adam Zawadzki ventured to make import-

${ }^{10}$ Katalog..., 1811, p. 27; Uwiadomienie..., [1854], p. 2.

11 V. Merkys, based on work of G. Shul'kina, points out that in 1805-1838 (before the death of the company's founder, J. Zawadzki) a total of 851 publications were printed at the firm's printing house and most of them were financed by the man himself (Merkys, 1972, p. 234; Shul'kina, 1962, pp. 99-119).

12 Motiejus Valančius (1801-1875) was a bishop, a public figure, writer, and national educator. In 1850, following his consecration as Bishop of Samogitia, he took on various types of activity: he reorganized the diocese and the theological seminary, initiated the temperance movement, participated in the education of children and adults, developed a wide network of parochial schools, and wrote, censored, and distributed religious literature in Lithuanian. 
ant business decisions and establish a branch of his Vilnius bookstore in Varniai to support complicated Vilnius affairs (Cybulski, 1972, p. 237).

In 1854-1865, Lithuanian books already accounted for almost a fifth of all of the company's publications, or a third of all Lithuanian books published at that time. Clarifying the data given by Ludwik Abramowicz, it may be stated that the firm published 605 publications at that time, including 348 (57,6\%) in Polish, $114^{13}(18,9 \%)$ in Lithuanian, 107 in Latin (17,6\%), 25 in Russian (4,1\%), and $11(1,8 \%)$ in French and German.

Given that Adam Zawadzki was connected to people from the environment of Motiejus Valančius, the repertoire of his Lithuanian-language publishing consisted mostly of mass-demand publications on religious topics. ${ }^{14}$ The entrepreneur actively published catechisms, prayer books, hymnals, Bible excerpts and other religious publications compiled by Motiejus Valančius, Jeronimas Kiprijonas Račkauskis, Juozapas Silvestras Dovydaitis, Pranciškus Ambraziejus Kašarauskas and others, reprinting more popular of them in the threefold increased print run. His publications essentially renewed the repertoire of the Lithuanian religious book and developed it in regard to quantity.

Adam's production of secular Lithuanian books was modest in the number of titles: nine school primers (of them, seven editions of Mokstas skaytima [...] (Science of reading [...]), eleven calendars (1855-1863) edited by Laurynas Ivinskis, two editions $(1860,1863)$ of Genawejte [...], a novella by Christoph von Schmid translated by Ivinskis, two informational bibliographic publications (book trade catalogues for 1858 and 1863) and four editions of the booklet Apej brostwa blaiwistes arba nusiturieima (About the brotherhood of temperance or abstention).

Compiled in the second half of the $18^{\text {th }}$ century, the textbook Mokstas skaityma raszta lietuwszka diet mazu wayku [...] (The science of reading Lithuanian script for small children [...]) was the first abecedary in Lithuania (Rabačiauskaitè, Korsakaite, 2000, pp. 21-22). It established the practice of using textbooks specifically created for teaching the mother tongue and started a new age in the primary education in Lithuanian schools. As a mass-demand publication, this primer was published by institutional and later, by private, printing houses engaged in the publishing of Lithuanian books. The Zawadzki firm was no exception.

Convinced of the success of the first Lithuanian calendar project, A. Zawadzki resolved, in 1855, to take over the publishing of Lithuanian calendars Metu skajtlus

13 According to the data of L. Abramowicz (1925, p. 95), 105, rather than 114, books were marked as published by the Zawadzki firm, so its total publishing output, according to him, would have been 596 publications.

14 During the period of Adam Zawadzki's leadership, the firm published 94 religious books, which made about $80 \%$ of all Lithuanian-language publications produced by the firm. 
ukiniszkas $[\ldots]^{15}$ (The housewife's year counter) compiled by Laurynas Ivinskis. After seven years of printing the calendars compiled and financed by L. Ivinskis, he began doing it at his own expense and even increased the print run. Zawadzki made them even more popular secular publications. Calendars partly carried out the function of Lithuanian periodicals, supplementing the reading matter of Lithuanian readers with texts on various practical topics, folklore and original fictional literature.

It is thanks to A. Zawadzki that the Lithuanians were able to read a sentimental didactic novella for young adults written by German writer Christoph von Schmid, Genawejte [...], which had already become a bestseller in Europe. After L. Ivinskis translated this novella from Polish, Zawadzki published it in two editions and made it Lithuania's first $19^{\text {th }}$ century fiction bestseller.

Taking the initiative to publish the first special Lithuanian book trade catalogues, ${ }^{16}$ Zawadzki increased the relevance and diversification of Lithuanian book content and added the first bibliographic publications to the repertoire of Lithuanian publications.

Another publication attributed to Adam Zawadzki was the booklet Apej brostwa blaiwistes arba nusiturieima (About the brotherhood of temperance or abstention) compiled by Motiejus Valančius and printed six times in 1858-1861, becoming the $19^{\text {th }}$-century Lithuanian publication with the largest print run. The booklet was intended for sobriety fraternities, which were being set up in 1858 in both the Vilnius and the Samogitian dioceses. According to research into the history of the Catholic Church, the sobriety movement in Lithuania became a mass folk movement that reached its highest point in 1860 (Šenavičienè, 2005, pp. 213-240). Even though another publisher is indicated in four of the editions of this booklet (Ed. Vaikinis and Co Printing House in Klaipeda ${ }^{17}$ ), recent research shows that the title pages of these editions contain falsified publication data. ${ }^{18}$ After most

15 Later, the title was changed to Kalendorius, arba Metu skajtlus ukiszkas [...] (1847).

16 Knigas..., [1858], p. [2]; Spis..., [1863], pp. 7-8.

17 The printing house of E. Vaikinis operated in Klaipeda in Lithuania Minor between 1855 and 1866. It published eight books intended for the market of Lithuania Minor, and also sold its own publications and those printed by others.

18 In historiography, researchers' opinions on the publishers of the book Apej brostwa blaiwistes arba nusiturieima differ. The first researcher who raised this idea and attempted to justify it was, in fact, Kazimierz Gieczys, who defended his doctoral thesis, Bractwa trzeźwości w diecezji żmudzkiej w latach 1858-1863, in the Department of Theology at the Stefan Batory University in Vilnius, and later published it in Vilnius in 1935 (Gieczys 1935). He based his hypothesis on files found at the Chancellery of the Governor General of Vilnius, which provided detailed administrative correspondence about the temperance movement (currently stored at the Lithuania State Historical Archive), the correspondence of the Zawadzki enterprise, and a study of several no longer extant editions of Apej brostwa blaiwystes. Gieczys claimed that both the 1858-59 and later editions of the booklets on temperance were printed not at the printing house of E. Vaikinis in Klaipeda, as indicated on the title page, but rather by Zawadzki in Vilnius. In his view, due to the start of gov- 
of the print run of the first edition was confiscated, the publisher looked for a way to avoid conflicts with the censors and to continue publishing a publication that was in such a high demand. In 1860, the booklet, printed by Zawadzki in Vilnius with falsified printing data on title page, became the first $19^{\text {th }}$ century Lithuanian contrafaction. The Vilnius publisher opted for an illegal publishing model, which justified itself at the time and continued to do so after press ban in 1864. Already in the first decades of the press ban on the initiative of M. Valančius the publishing of Lithuanian book for Lithuanian reader's demands was organized in Lithuania Minor, and the books were illegally distributed in Lithuania (usually as counterfeit copies, with forged edition data, and with a note on the title page stating that they were printed by the company of J. Zawadzki in the years before the press ban). The press ban lasted until 1904, and for all four decades, this model of publishing was the most popular and helped to provide Lithuanian publications to the Lithuanian population.

The publishing initiatives of Adam Zawadzki received support and encouragement from Lithuanian intellectual circles; Lithuanian book authors, in their letters to the publisher, indicated the publications of the highest demand, sent new manuscripts, often refusing royalties, constantly urged him to supply Lithuanian books to the Varniai bookstore, ${ }^{19}$ the only stationary bookstore open in the periphery of Lithuania (Petkevičiūtè, 1984, pp. 44-51; Navickienè, 1996, pp. 34-44), and helped to distribute the books both at and outside the bookstore.

ernment repression, the booklet and its distribution were banned immediately after publication and part of the edition was confiscated. Subsequent editions were then issued with false publishing information. However, this view is not shared by all researchers. Lithuanian bibliographers Silvestras Baltramaitis (1904) and Vaclovas Biržiška (1926; 1929) did not think that the 1860-61 editions of Apej brostwa blaiwystes were counterfeit. The opinions of today's researchers on this matter are likewise different. Domas Kaunas, a book researcher interested in the publishing history of Lithuania Minor based on the works of Lithuanian bibliographers, claims that Valančius had established a relationship with Vaikinis (Kaunas, 1986, p. 75; 1996, p. 274). Some other historians base their interpretations on this opinion from D. Kaunas. Historian Vytautas Merkys is of the same opinion and discusses the publication of literature on the temperance movement in his monograph on Motiejus Valančius (Merkys, 1999, p. 350); historians Antanas Tyla (1969, pp. 93-107) and Zita Medišauskienè $(1998$, p. 259) are also in agreement with D. Kaunas. Other historians agree with K. Gieczys and the idea of contrafaction. Egidijus Aleksandravičius does so in his study about temperance in nineteenth-century Lithuania (Aleksandravičius, 1990). The author of this article agrees with Gieczys as well, having first stated her opinion on the subject in 1992's paper, and later reinforced it by further research and summarized in a study specially addressing this issue (Navickienè, 1992, 2005; 2016).

19 [Akelaičio...], 1856; [Budriko...], 1856; Daukantas, 1976; [Gomaliausko...], 1851; Ivinskio..., 1995, pp. 403-491; [Ivinskio Lauryno...], 1850-1861; [Juzumų...], 1854-1856; [Kun. Ulinskio...], 1858; Navickienè, 2007; [Praniausko...], 1854-1861; [Prialgauskio...], 1859; [Račkauskio Jeronimo laiškai Adomui Zavadzkiui], 1853-1861; [Račkauskio Jeronimo laiškas Juozapo Zavadzkio knygynui], 1856; [Skrodzkio...], 1856; [Valančiaus...], 1851; [Želvavičiaus...], 1850-1860. 
An examination of the extant registration journals for the books sold through the Vilnius and the Varniai bookstores showed that Lithuanian publications of Adam Zawadzki reached their readers via bookstores, as well as using non-stationary and seasonal trade forms. While in 1840-1844, only a few Lithuanian publications were sold at the Vilnius bookstore; their percentage grew with the increase of the number of Lithuanian books in Zawadzki's output. In 1853, the store sold 84 items of Lithuanian books; in 1854, 3 249; in 1856, 1 516; and in 1862, 1330 items. ${ }^{20}$ However, the majority of Zawadzki's publications were sold in Varniai, a small town the west of Lithuania. Thanks to the efforts of M. Valančius and A. Zawadzkis in the sixth decade, the Varniai with the Priests' Seminary, the Bishop of Samogitia's residency and the stationary bookstore became a centre of Lithuanian culture and book trade. The enterprise brought Lithuanian books significantly closer to their main readers - Lithuanian-reading peasants and some of the petty noblemen ${ }^{21}$ - and accelerated the capital turnover cycle. Throughout the whole year, boxes of books were being carried from Vilnius to Varniai, both by postal horses and carts rented by the Jews. Through the efforts of Motiejus Valančius, a postal road was built through Varniai, speeding up communication and making traders' journeys easier. Money for the sold books traveled from Varniai to Zavadzki's bookstore in Vilnius by the same roads, most often by post. An average of 10000 items was sent from Vilnius to the Varniai bookstore, and in 1859, these numbers ran to $50000 .^{22}$

In the Varniai bookstore in 1853, Lithuanian books constituted $25 \%$ of all the publications sold by the store; in $1854,35 \%$; and in $1859,69 \%$; while in 1863 , their percentage rose as high as $77 \% .{ }^{23}$ Over the entire reference period, the store received more than 40000 copies of the prayer book Senas auksa attorius [...] (Old gold digger [...]), 20000 copies of the book Katwaria, arba Kialas kriziaus sopulun Jezusa Kristusa [...] (Kałwaria, or Way of the Cross as the journey of the Pain of Jesus Christ [...]), 18000 copies of the officially-confirmed catechism Aktas ir poteryj [...] (Act and prayers [...]), 14000 copies of the prayer book Roźanczius Szwęcziausios Marios Panos yr saldżiausi warda Jezusa [...] (The rosary of St. Virgin Mary and the sweet name of Jesus [...]). The number of copies of 35 other titles of religious books sent to Varniai varied from 500

${ }^{20}$ Calculated based on the following sources: Kniga registratsii prodazhi knig, 1861-1862; 1864-1866; Kniga registratsii prodazhi knig, khudozhestvennoy literatury, uchebnikov, slovarey, 1853-1856; Kniga registratsii prodazhi not, knig i periodicheskikh izdaniy, 1861-1863.

21 In this part of Lithuania, the process of Polonization was the slowest; the network of elementary and secondary schools, the densest; and the literacy of the population, the highest.

22 Calculated based on the following sources: Zhurnal..., 1853-1865; Kniga registratsii otpravlennykh zakazov knig, 1853-1865.

23 Kniga registratsii otpravlennykh knig v Vorni i Shidlovo, 1853-1863. 
to 7000 for each title (Navickienè, 2010, pp. 235, 338-341). These were prayer books, catechisms, publications on religious ethics, and various religious readings compiled by M. Valančius, J.K. Račkauskis, the Juzumai brothers, J.S. Dovydaitis, Kazimieras Prialgauskis, Kazimieras Skrodzkis and other authors (books published by Adam Zawadzki or the authors themselves). In addition to religious Lithuanian books, the Varniai bookstore was a venue of distribution of more than 15 titles of secular books. In ten years, the Varniai bookstore received from Vilnius almost 35000 copies of calendars edited by L. Ivinskis, 20000 copies of school primers Mokstas skaytima raszta lietuwiszka dieł mażu wayku [...], a few thousand textbooks by the brothers Juzumas, 1300 copies of the Genawejte (a novella by Christoph von Schmid translated by Ivinskis) and over 10000 publications promoting sobriety: 3000 copies of Gyrtibe yr blajwiste (Drunkenness and sobriety) by K. Kasakauskis, 1600 copies of Pasaka apej pasznekiesni tarp welnia yr szimkorju (Conversation between the devil and the innkeeper) by the same author, and about 7000 copies of the novella Sziauleniszkis senelis (A grandfather from Šiaulènai [...]) by J.S. Dovydaitis (Navickienè, 2010). Ivinskis's calendars and the primer Mokstas skaytima raszta lietuwiszka diet mażu wayku [...] were as much popular as the mass-demand ritual and prayer books.

In 1853-1864, the Varniai bookstore also served as a venue for wholesale trade. 32 small merchants took books on credit from this store. ${ }^{24}$ They sold Lithuanian books in the cities and towns of Raseiniai, Telšiai, and Šiauliai counties, as well as in Šiluva, Kalvarija, Telšiai, Viešvènai, Užventys, Kelmè, and Jurbarkas. 55 clergymen from the entire Diocese of Samogitia purchased Lithuanian books from the Varniai bookstore, probably also for distribution purposes (Navickiené, 2010 , pp. 256, 343). They each bought five or more titles and dozens of copies. The addresses of the distributors show that they lived in all seven counties of the Kaunas province. Invoices for the books bought by small merchants from both the Vilnius and Varniai bookstores fully reflect the section of the bookstore's range of Lithuanian books consisting of Adam Zawadzki's publications on religious practice and primary education.

Adam Zawadzki used his father's experience to good advantage, focusing on advertising his publications. Until the sixth decade, Lithuanian books were advertised together with the company's other books. After the establishment of the Varniai bookstore, attention to the advertisement of Lithuanian books grew. The publisher began compiling special commercial lists of Lithuanian books and printing them on the last pages or covers of the books slated for sending to Varniai. These lists may be the first manifestation of autonomous Lithuanian book advertising, a new phenomenon in the Lithuanian book trade of Lithuania (30 such lists were

${ }^{24}$ Zhurnal..., 1853-1865. 
successfully identified, but even more of them could have existed from 1853-1864 (Navickienè, 2010, p. 271)).

With an increase in the volume of publishing, in 1858 a bibliographic publication for the Lithuanian book trade appeared as a separate publication for the first time in the history of the books of Lithuania. It was a book trade catalogue distributed free of charge and intended especially for advertising Lithuanian books sold by the Varniai bookstore ${ }^{25}$ (On $14^{\text {th }}$ November 1858, a description of 25 publications from Zawadzki's firm, approved by the censor P. Kukolnik, was printed on two separate sheets and sent to the Varniai bookstore on $9^{\text {th }}$ January 1859 in 200 copies).

Another, more expanded, catalogue came out in 1863. It was based on the publication of 1858 and supplemented by a dozen new entries. ${ }^{26}$ The new catalogue contained information on 36 publications from the Zawadzki firm. While the catalogue of 1858 was specifically intended for the Varniai bookstore, that of 1863 was also distributed through the Vilnius bookstore.

The Zawadzki firm's Lithuanian book publishing, which had successfully lasted for a decade, was halted by the uprising of 1863-1864, and soon completely stopped by the ban on printing in the Latin alphabet. In the 1860 s, the company lived through its most difficult times and was even on the verge of collapse. Even without taking into account the repressions, it was almost insolvent. The Lithuanian press was prohibited, and the Polish press was severely restricted. Only in the 1870 s would the firm's position became more stable.

\section{CONCLUSIONS}

The Zawadzki firm represented the category of professional publishers. Together with other private book printing and distribution companies, which most often were family-owned, it replaced the old Catholic Church printing houses, which had previously dominated the publishing of Lithuanian books. Over the first seventy years of the firm's existence, it printed 172 Lithuanian books, and about 122 Lithuanian publications were printed at the firm's finances. During that period, the attitude of the members of Zawadzki family regarding the publishing of Lithuanian books essentially changed. While Józef Zawadzki was indifferent towards them, his son Adam became the most important publisher of Lithuanian books. When, in the fifth decade of $19^{\text {th }}$ century, the Catholic Church, especially in the Samogitian Diocese, became invested in the Lithuanization of the pastoral care and in the creation of Lithuanian texts for primary education and religious prac-

\footnotetext{
25 Knigas..., [1858], p. [2].

26 Spis..., [1863], p. 8.
} 
tice, and when the part of society able to afford Lithuanian books had increased, it was commercial interest that drove Adam to publish Lithuanian books. He viewed the Lithuanian reading population as a collective benefactor of publishing, so he took advantage of the possibilities it offered and provided it with mass-demand publications intended for religious practice, primary education and leisure reading.

In the middle of the $19^{\text {th }}$ century, Adam Zawadzki outcompeted other professional book publishers and distributors, and monopolized the publishing of Lithuanian books in the Samogitian Diocese, becoming not only the most important publisher of Lithuanian books, but also their printer and distributor. His publishing activities contributed to quantitative and qualitative changes in the repertoire of Lithuanian books, to the appearance of valuable fiction, and to the first calendars and bibliographical publications in Lithuanian. The successful realization of Zawadzki's business plans was due partly to his longstanding contacts with the most active figures of Lithuanian written culture, with whom he maintained a new form of cooperation based on authorial royalties, partly due to effective distribution of published matter, using the first stationary bookstore in the province, located in the west of Lithuania (which served as a retail and wholesale trade enterprise), various ways of non-stationary book trade, and the services of a commercial library and advertising. As an innovative publisher, he applied the models of publishing based on private capital, and used the methods of fundraising and dissemination characteristic for modern publishing.

Owing to Adam's efforts, the Zawadzki firm made a significant contribution uniting main forces of authors and publishers of Lithuanian books in $19^{\text {th }}$ century Lithuania and renewing the repertoire of Lithuanian books. It is due to the Zawadzki firm that publishing, production and distribution of Lithuanian books gained features characteristic for a modern business. A model of dealing with censorship through illegal publishing, developed with the publication Apej brostwa btaiwistes arba nusiturieima, was used throughout all forty years of the press ban and helped raise several generations of literate Lithuanians, bringing Lithuania and Lithuania Minor closer together.

\section{BIBLIOGRAPHY}

\section{ARCHIVAL SOURCES}

[Akelaičio Mikalojaus laiškai Adomui Zavadzkiui]. (1856). Lietuvos mokslų akademijos Vrublevskių biblioteka, f. 7, b. 536b.

[Budriko Dominyko laiškas Adomui Zavadzkiui]. (1856). Lietuvos mokslų akademijos Vrublevskių biblioteka, f. 7, b. 567.

[Gomaliausko Petro laiškas Adomui Zavadzkiui] (1851). Lietuvos mokslų akademijos Vrublevskių biblioteka, f. 7, b. 623 . 
[Ivinskio Lauryno laiškai Adomui Zavadzkiui] (1850-1861). Lietuvos mokslų akademijos Vrublevskių biblioteka, f. 7, b. 647 .

[Juzumų, Antano ir Vincento, laiškai Adomui Zavadzkiui] (1854-1856). Lietuvos mokslų akademijos Vrublevskių biblioteka, f. 7, b. 668 .

[Kun. Ulinskio laiškas Adomui Zavadzkiui] (1858), Lietuvos mokslų akademijos Vrublevskių biblioteka, f. 7, b. 890.

[Praniausko Otono laiškai Adomui Zavadzkiui] (1854-1861), Lietuvos mokslų akademijos Vrublevskių biblioteka, f. 7, b. 818,882 .

[Prialgauskio Kazimiero laiškas Adomui Zavadzkiui] (1859). Lietuvos mokslų akademijos Vrublevskių biblioteka, f. 7, b. 823 .

[Račkauskio Jeronimo laiškai Adomui Zavadzkiui] (1853-1861). Lietuvos mokslų akademijos Vrublevskių biblioteka, f. 7, b. 825 .

[Račkauskio Jeronimo laiškas Juozapo Zavadzkio knygynui] (1856). Lietuvos mokslų akademijos Vrublevskiu biblioteka, f. 7, b. 826 .

[Skrodzkio Kazimiero laiškai Adomui Zavadzkiui] (1856). Lietuvos mokslų akademijos Vrublevskių biblioteka, f. 7, b. 853 .

[Valančiaus Motiejaus laiškai Adomui Zavadzkiui] (1851). Lietuvos mokslų akademijos Vrublevskių biblioteka, f. 7, b. 921.

[Želvavičiaus Juozapo laiškai Adomui Zavadzkiui] (1850-1860). Lietuvos mokslų akademijos Vrublevskių biblioteka, f. 7, b. 944 .

Kniga registratsii otpravlennykh knig v Vorni i Shidlovo (1853-1863). Lietuvos valstybės istorijos archyvas, f. 1135, ap. 7, b. 106.

Kniga registratsii otpravlennykh zakazov knig (1853-1865). Lietuvos valstybės istorijos archyvas, f. 1135, ap. 7, b. 109;

Kniga registratsii prodazhi knig (1861-1862). Lietuvos valstybės istorijos archyvas, f. 1135, ap. 7, b. 103;

Kniga registratsii prodazhi knig (1864-1866). Lietuvos valstybės istorijos archyvas, f. 1135, ap.7, b. 130 .

Kniga registratsii prodazhi knig, khudozhestvennoy literatury, uchebnikov, slovarey (1853-1856). Lietuvos valstybès istorijos archyvas, f. 1135, ap. 7, b. 105;

Kniga registratsii prodazhi not, knig i periodicheskikh izdaniy (1861-1863). Lietuvos valstybès istorijos archyvas, f. 1135, ap. 7, b. 123.

Perepiska s Vilenskim Grazhdanskim Gubernatorom o chisle napechatannykh s odobreniyem Vilenskogo Tsenzurnogo komiteta knig v 1829-30-31-32-33-41-42-43 godakh, 8 fevralya-14 marta 1844, Lietuvos valstybės istorijos archyvas, f. 1240, ap. 1, b. 60, lap. 4 [v]-5.

Zhurnal registratsii zakazov na knigi religioznogo soderzhaniya, noty i periodicheskuyu pechat', 1853-1865, Lietuvos valstybès istorijos archyvas, f. 1135, ap. 7, b. 107, lap. 44.

\section{REFERENCES}

Abramavičius, V. (1955). L. Ivinskis ir Zavadzkio leidykla, Pergale, 5, 74-90.

Abramavičius, V. (1940). Zavadzkiai ir lietuviškoji knyga Vilniuje. Vilnius.

Abramowicz, L. (1925). Cztery wieki drukarstwa w Wilnie: zarys historyczny (1525-1925). Wilno.

Aleksandravičius, E. (1990). Blaivybė Lietuvoje XIX amžiuje. Vilnius: Sietynas.

Baltramaytis, S. (1904). Spisok litovskikh i drevne-prusskikh knig, izdannykh dlya geografii, istorii, istorii prava, statistiki i etnografii Litvy. Sankt-Peterburg.

Biržiška, V. (1926). Lietuviu bibliografija, D. 2, 1800-1864 m. Kaunas: Švietimo ministerijos leidinys.

Biržiška, V. (1929). Antrosios Lietuvių bibliografijos dallies (1800-1864) papildymai. In: Lietuviu bibliografija, D. 3. Kaunas. 
Cybulski, R. (1960). Asortyment księgarni na początku XIX w. Księgarz, 6, 10-14.

Cybulski, R. (1963). Księgarstwo polskie na początku XIX w. Księgarz, 3, 46-57.

Cybulski, R. (1972). Józef Zawadzki-księgarz, drukarz, wydawca. [Wrocław]: Ossolineum.

Cybulski, R. (1976). Formowanie się modelu kapitalistycznego przedsiębiorstwa wydawniczo-księgarskiego w Polsce w latach 1800-1831. Studia o Książce, 6, 101-130.

Daukantas, S. (1976). Laiškai. In: S. Daukantas, Raštai (pp. 709-792). Vilnius.

Estreicher, K. (1870). Bibliografia polska, T. 1. Kraków.

Gieczys, K. (1935). Bractwa trzeżwości w diecezji żmudzkiej w latach 1858-1864: Dysertacja doktorska. Wilno.

Griškaitė, R., Šenavičienė, I. (1996). Varnių knygyno korespondentai (1835-1871). In: Varniai (pp. 64-70). Vilnius.

Ivinskio, L. (1995). Laiškai. In: L. Ivinskis, Raštai (pp. 403-491). Vilnius.

Katalog ksiag polskich [...] Józefa Zawadzkiego, Cz. 1 (1811). Wilno.

Kaunas, D. (1986). Iš lietuvių knygos istorijos: Klaipédos krašto lietuviška knyga iki 1919 m. Vilnius: Mokslas.

Kaunas, D. (1996). Mažosios Lietuvos knyga: lietuviškos knygos raida 1547-1940. Vilnius: Baltos lankos.

Knigas źemajtiszkas iszduotas kasztu ir spaustuwi Jozapa Zawadzkia Wilniuje, o kurios gal kiekwienas pirkti Warniusie kniginiczio to paties Jozapa Zawadzkia: [katalogas], [Vilnius] [1858].

Lietuvos bibliografija. Serija, A. Knygos lietuvių kalba (1990). T. 1. 1547-1861. Papildymai. Vilnius.

Lietuvos TSR bibliografija. Serija, A. Knygos lietuvių kalba (1969-1988.). T. 1-2. Vilnius.

Medišauskienè, Z. (1998). Rusijos cenzūra Lietuvoje XIX a. viduryje. Kaunas: Vytauto Didžiojo universitetas.

Merkys, V. (1972). Lietuvos poligrafijos įmonès 1795-1915 m. In: J. Jurginis, Spauda ir spaustuvès. Vilnius: Mintis.

Merkys, V. (1999). Motiejus Valančius: tarp katalikiškojo universalizmo ir tautiškumo. Vilnius: Mintis.

Migoń, K. (2009). Natsional'naya (etnicheskaya) kniga v Yevrope kontsa XIX-nachala XX veka. Knygotyra, 52, 186-196.

Navickienè, A. (1992). Lietuviškų knygų leidèjai ir jų leidiniai. Knygotyra, 19, 11-26.

Navickienė, A. (1996), Juozapo Zavadzkio firmos lietuviškų leidinių platinimas. Knygotyra, 20, 34-44.

Navickienè, A. (2005). Kontrafakcija XIX a. pirmosios pusės lietuviškų knygų leidyboje. Knygotyra, 44, 60-71.

Navickienè, A. (2007). Mikalojaus Akelaičio laiškai Adomui Zawadzkiui. Knygotyra, 49, 188-213.

Navickienè, A. (2010). Besikeičianti knyga XIX amžiaus pirmosios pusès Lietuvoje. Vilnius: Vilniaus universiteto leidykla.

Navickienè, A. (2016). "Contrafaction" in Lithuanian book publishing in the first two - thirds of the nineteenth century: The publication of Apej brostwą blaivystes, (R. Vaičekonytè, Trans.), Lingua Franca: The History of the Book in Translation, 2, 1-18. http://www.sharpweb.org/main/wp-content/uploads/2016/06/Navickiene_Paper.pdf

Petkevičiūtè, D. (1984). J. Zavadskio skaitykla Varniuose 1853-1856 m. Knygotyra, 12, 44-51.

Poklewska, D. (1972). Zawadzki. In: Słownik pracowników ksiązki polskiej (1010-1014). Warszawa, Łódź: Państwowe Wydawnictwo Naukowe.

Rabačiauskaitè, A., Korsakaitė, I. (Eds.). (2000). Lietuviški elementoriai. Kaunas: Šviesa.

Rozet, R.I. (1960). Yu. Zavadskiy i izdatel'skaya deyatel'nost' Vil'nyuskogo universiteta v pervom tridtsatiletii XIX veka. Vilniaus valstybinio, V. Kapsuko universiteto mokslo darbai, 32, 151-165.

Šenavičienè, I. (2005). Dvasininkija ir lietuvybè: Kataliku bažnyčios atsinaujinimas Žemaičiu vyskupijoje XIX a. 5-7 dešimtmetyje. Vilnius: LII Leidykla. 
Shul'kina, G. (1962). Rol' Bil'nyusskoy tsenzury v razvitii izdatel'skogo dela v 1803-1832 godakh. Bibliotekininkystès ir bibliografijos klausimai, 6, 99-119.

Spis dziet dla pierwiastkowego kształcenia przeznaczonych, znajdujacych się w Księgarni pod firma Józefa Zawadzkiego w Wilnie. [Vilnius] [1863].

Turkowski, T. (1935-1937). Materjały do dziejów literatury i oświaty na Litwie i Rusi z archiwum drukarni i księgarni Józefa Zawadzkiego w Wilnie z lat 1805-1865, T. 1-3. Wilno.

Tyla, A. (1968). Pastabos dèl lietuviškos knygos istorijos. Lietuvos TSR Aukštujų mokyklu mokslo darbai. Bibliotekininkystès ir bibliografijos klausimai, 7, 99-119.

Tyla, A. (1969). Motiejaus Valančiaus laiškai Adomui Zavadzkiui. Lietuvos TSR aukštuju mokyklu mokslo darbai. Literatūra, 11(10), 93-107.

Uwiadomienie o książkach polskich [...] Józefa Zawadzkiego [...], nr. 1. [Wilno] [1854].

AUŠRA NAVICKIENĖ

PROFESSIONAL PUBLISHING AND LITHUANIAN BOOKS

IN THE FIRST TWO-THIRDS OF THE 19TH CENTURY IN LITHUANIA: THE CASE OF THE ZAWADZKI FIRM

\section{Summary}

Successfully profiting from textbook publishing as the typographer at Vilnius University, Józef Zawadzki (1781-1838) established one of the most important and most successful book publishing, production, and distribution companies of the 19th and the first half of the 20th century in the territories of former Polish-Lithuanian Commonwealt. The Zawadzki firm represented the new category of professional publishers. Over the first seventy years of the firm's existence at the firm's expense were published 122 Lithuanian books, as well as printed about 50 Lithuanian publications at their authors finances. The attitude of the members of Zawadzki family regarding the publishing of Lithuanian books essentially changed. While the Józef Zawadzki was indifferent towards them, in the middle of the $19^{\text {th }}$ century Adam Zawadzki (1814-1875) outcompeted other professional book publishers and distributors, and monopolized the publishing of Lithuanian books in the Samogitian Diocese, becoming not only the most important publisher of Lithuanian books, but also their printer and distributor. The successful realization of Adam Zawadzki's business plans was partly due to his longstanding contacts with the most active figures of Lithuanian written culture, with whom he maintained a new form of cooperation based on authorial royalties, partly due effectively distribution of published matter, using first stationary bookstore in the periphery, located in the west of Lithuania (which served as a retail and wholesale trade enterprise), various ways of non-stationary book trade, services of a commercial library and advertising. Owing to Adam's efforts, the Zawadzki firm made a significant contribution uniting main forces of authors and publishers of Lithuanian books in 19th century Lithuania, renewing the repertoire of Lithuanian books, as well as giving Lithuanian book publishing, production and distribution features characteristic for a modern business. A model of dealing with censorship through illegal publishing, developed with the publication Apej brostwa blaiwistes arba nusiturieima, was used throughout all the forty years of the press ban and helped raising several generations of literate Lithuanians and bringing Lithuania and Lithuania Minor closer together.

KEY WORDS: Józef Zawadzki, Adam Zawadzki, nineteenth century publishing in Lithuania, Lithuanian books, Varniai book shop 